\title{
SOUTH ARMORICAN SHEAR ZONE AND CONTINENTAL FIT BEFORE THE OPENING OF THE BAY OF BISCAY *
}

\author{
Jean-Claude SIBUET \\ Centre Océanologique de Bretagne, B.P. 337, 29200, Brest, France \\ Received 10 October 1972 \\ Revised version received 10 November 1972
}

\begin{abstract}
-The relative position of continents prior to the opening of the Bay of Biscay can be correctly deduced from ro zonstruction of the Ibero-Armorican belt only if the extent of the Late-Hercynian horizontal displacement along the south Armorican shear zone and perhaps also along the north Pyrenean fault can be determined. -
\end{abstract}

Geological similarity between Hercynian zones from Brittany and the Iberian Peninsula has led various authors [1-3] to propose that these zones were once continuous. Bard et al. [3], for example, reconstruct the Hercynian Ibero-Armorican belt to find the position of the Iberian peninsula before the opening of the Bay of Biscay (150 to 200 my ago). They assume continuity of Hercynian structures of the Armorican massif over hundreds of kilometers across the continental shelf. This supposes that Late of Post Hercynian horizontal displacements have not significantly modified the original framework of the Hercynian massif. The purpose of this note is to discuss, on the basis of new results, the importance of the main Late or Post Hercynian horizontal movements which have taken place in Brittany and on the adjacent continental shelf and their implication for the fit of continents based on the reconstruction of the Ibero-Armorican belt.

The principal horizontal movements which may have affected the Ibero-Armorican belt after the main Hercynian orogeny are those which have occurred during Late Hercynian time along the south Armorican shear zone $[1,4]$. The south Armorican shear zone, which is an important Late Hercynian feature (figs. 1, 2 ), is roughly parallel to the main structural units in Brittany. The horizontal motion associated with the

\footnotetext{
- Contribution no. 117 of the Departement Scientifique, Centre Oceanologique de Bretagne.
}

shear zone could be several tens of $\mathrm{km} \mathrm{[5]} \mathrm{or} \mathrm{even}$ hundreds of $\mathrm{km}$ [6].

Recent seismic reflection and rock coring studies at sea [7-11] show that two major geological features of the Armorican massif can be followed up to $5.5^{\circ}$ longitude west (fig. 1). The granito-gneissiz dome of the Leon certainly extends seaward with the same $\mathrm{NE}$-SW trend up to $5.3^{\circ}$ longitude west and the "Chaussee de Sein" which marks the marine prolongation of the south Armorican shear zone extends at least up to $5.5^{\circ}$ longitude west. The Paleozoic central Armorican zone, which is located between the two preceding units, disappears at $5.5^{\circ} \mathrm{W}$ and does not exist south of the shear zone. In addition, the NE-SW metamorphic units of the Leon come nearly into contact with the E-W or ENE-WSW shear zone at $5.5^{\circ} \mathrm{W}$ and seem to be cut by the probable prolangation of the shear zone (fig. 1). This suggests that the south Armorican shear zone is a strike-slip fault, since its direction cuts across the main structural units in the Iroise sea. As shown in fig. 1, if one extends the south Armorican shear zone to the West with the same curvature it would reach the edge of the continental shelf at $47.5^{\circ} \mathrm{N}, 7.5^{\circ} \mathrm{W}$ precisely where the character of the continental slope changes abruptly.

A new free-air gravity map compiled with data from the Centre Océanologique de Bretagne, Cambridge University $[12,13]$, Bedford Institute, the Royal Netherlands Navy [14] and the French Service Hydrographique et Océanographique de la Marine is 


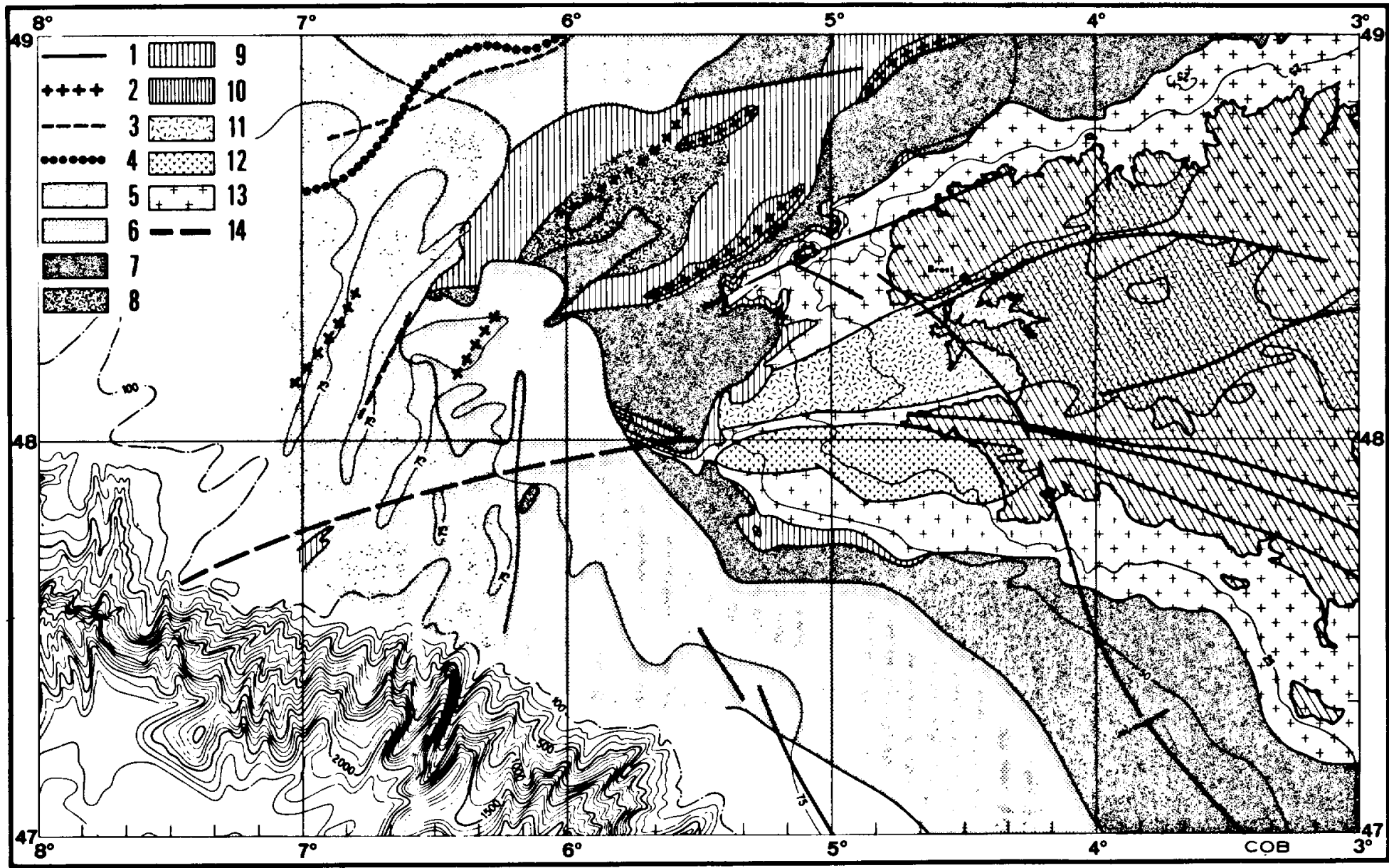

Fig. 1. Simplified geological map of Brittany and adjacent continental shelf [7-10]. Depths in uncorrected fathoms [21]. Legend: 1, fault; 2, anticline; 3, syncline; 4, paleo valley; 5, Plio-Quaternary; 6, Neogene; 7, Middle Eocene; 8, Lower Eocene; 9, Upper Cretaceous; 10, Lower Cretaceous; 11, Siluro-Devonian; 12 , amphibolites; 13, granites; 14, possible extension of the south-Armorican shear zone. 


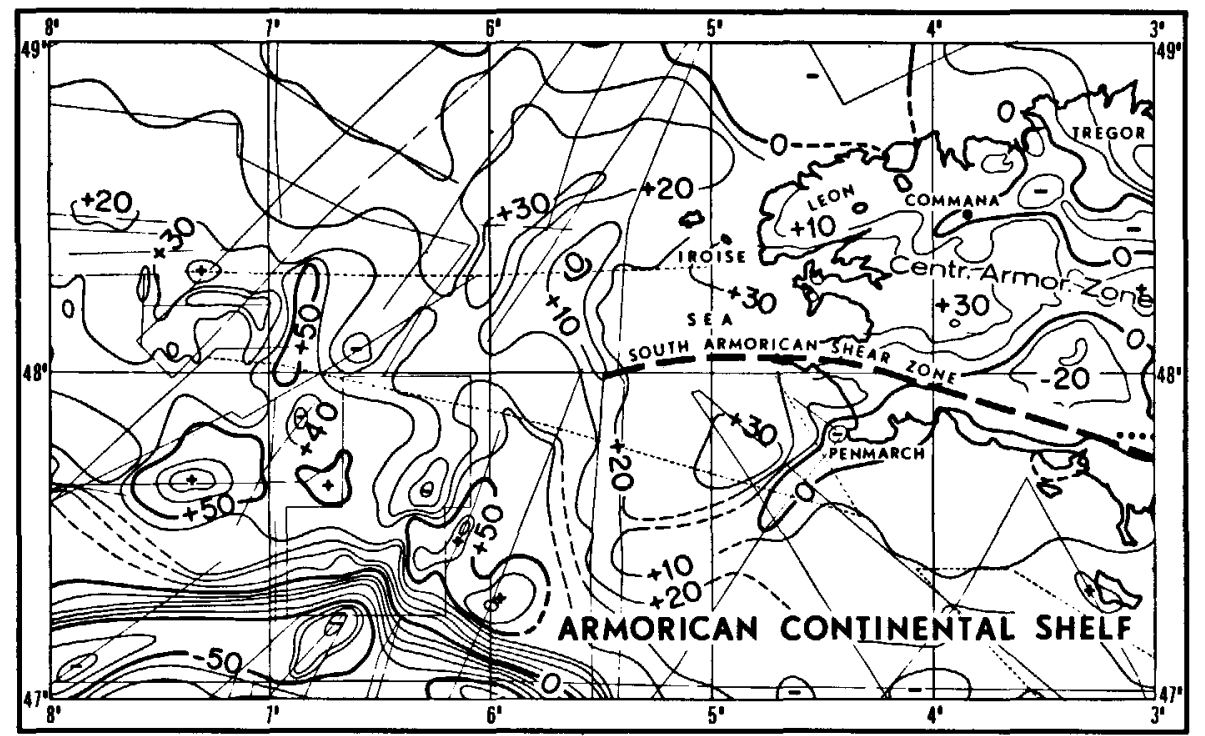

Fig. 2. Free-air gravity anomaly map of Brittany and adjacent continental shelf completed with Bouguer anomalies on land [15, 16]. Contour interval is $10 \mathrm{mgal}$. Dashed lines are tracks from Centre Océanologique de Bretagne and full lines are tracks provided by other laboratories (see text).

presented in fig. 2 . The accuracy of the data is better than $10 \mathrm{mgal}$. On land, Bouguer anomalies have been used $[15,16]$. The agreement between the two types of anomalies is good because the water layer is thin (less than $200 \mathrm{~m}$ ), land relief low (200 m maximum) and the edge of the continental margin quite distant. Two main features can be recognized on this map. One is the Late Hercynian shear zone and the granitic intrusions associated with it, the other is the contrast in patterns north and south of this zone.

With few exceptions, granites of the Armorican massif are associated with negative anomalies $[17,18]$. The two large negative bands of anomalies in Brittany correspond first to the metamorphic and granitic units of the Leon and to the granitic complex extending eastward from Comana and second to units such as the south Armorican shear zone and associated granitic intrusions. Extension towards the continental shelf of these granites is quite limited. Only the granitic massif of Penmarch could have dimensions similar to granitic intrusions located north of the shear zone (fig. 2). On either side of the belt of anomalies related to the shear zone and associated granitic units, one notes contrasting patterns of gravity anomalies. To the north, gravity anomalies outline the EW to ESE-WNW Paleozoic or earlier structures, as for example the EW anomalies north of the Loire river or the ESE-WNW anomalies associated with the Lanvaux granitic lineament. To the south, the gravity anomaly pattern is featureless except perhaps a few EW anomalies of 20 mgal amplitude on the Armorican continental shelf.

This difference in pattern agrees with the idea that the south Armorican shear zone has acted as a shear fault; the horizontal motion along this Late Hercynian fault brought into contact two regions with differing geology. On this basis, the horizontal displacement has to be of the order of several hundred kilometers.

The south Armorican shear zone is quite extensive in Brittany but does not exist in Spain (fig. 3). It seems therefore to have separated the Hercynian belt of Spain from the portion of the Hercynian belt of Brittany located north of the shear zone. Fig. 3 shows the position of the Iberian peninsula before the opening of the Bay of Biscay. This position has been calculated from transform directions in the Bay and on adjacent land $[19,20]$. In order to further reconstruct the original Ibero-Armorican belt, the displacement due to the south Armorican shear zone and perhaps to the north Pyrenean fault has to be removed. The proposed scheme for the role of the shear zone is shown in fig. 4. 
J.C. Sibuet, South Armorican shear zone and continental fit

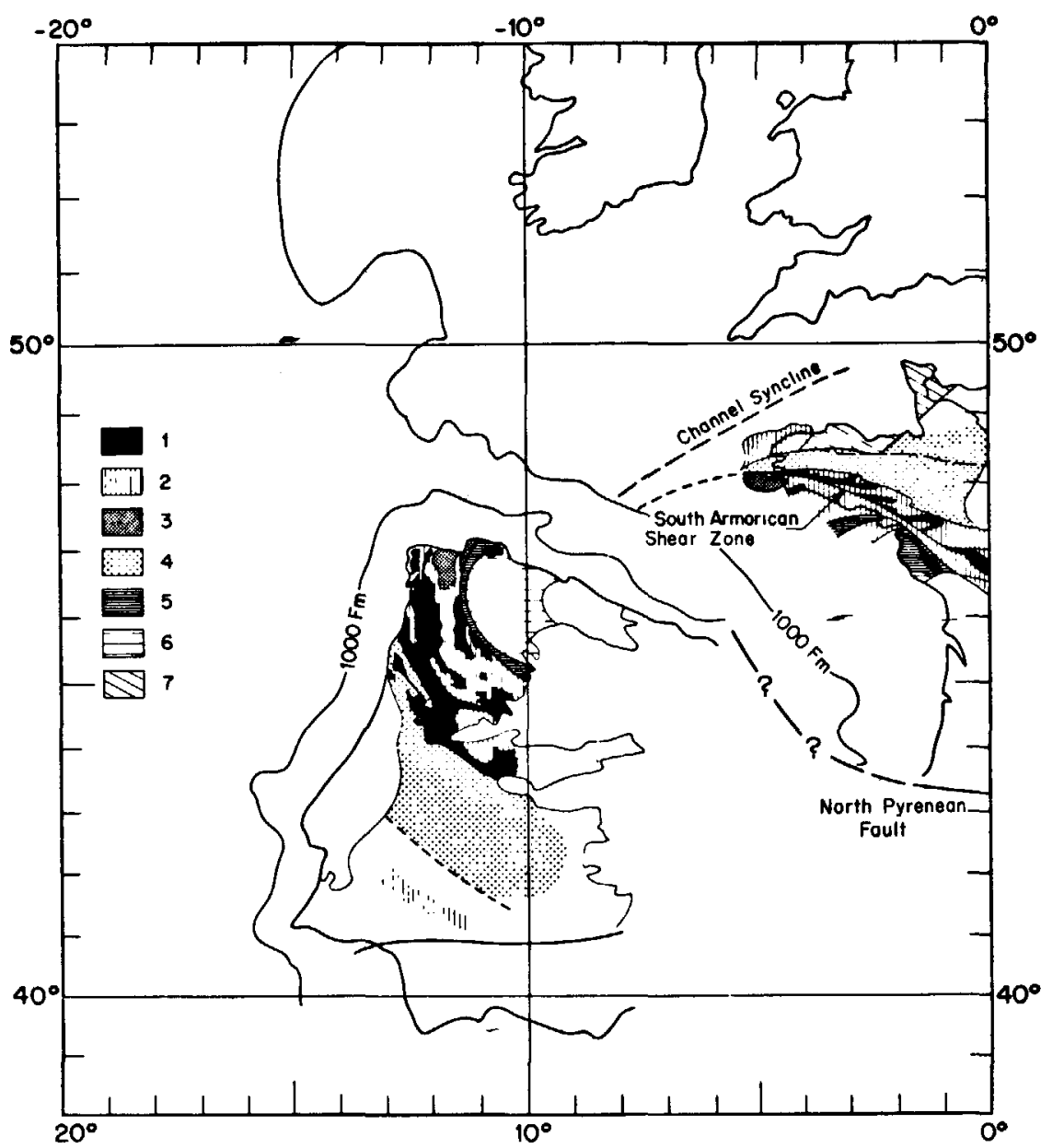

Fig. 3. The Iberian Peninsula has been rotated $23^{\circ}$ clockwise about a pole at $50.0^{\circ} \mathrm{N} ; 3.3^{\circ} \mathrm{E}[19,20]$. Stratigraphic Hercynian correlations between Iberian peninsula and Armorican massif are shown [2]. 1, Syntectonic leucogranites; 2, Orthogneisses and other metamorphic rocks of the axial zone; 3 , Acid, basic and ultrabasic complexes of catazones; 4, Central Armorican zone and central Iberian zone; 5, Schists and porphyroids of Vendee and Cevennes correspond to 6, Ollo do Sapo Series from Spain; 7, Pentevrian basement.

a

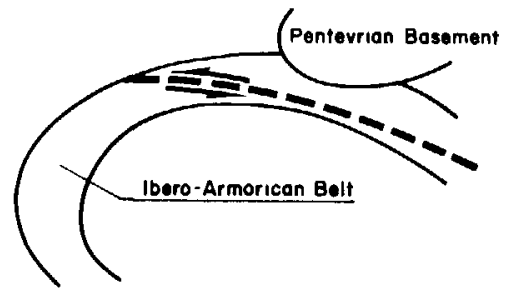

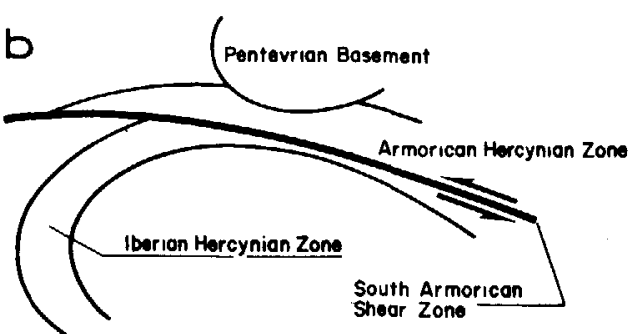

South Armoricon

Fig. 4. Sketch of the Hercynian Ibero-Armorican belt before (a) and after (b) the movement along the south Armorican shear zone. For illustrative purposes the motion along the shear zone has been taken as left-lateral. 


\section{J.C. Sibuet, South Armorican shear zone and continental fit}

Any reconstruction of the original relative positions of continents before the opening of the Bay of Biscay based on continuity of the lbero-Armorican belt will be uncertain as long as the direction and the amplitude of the horizontal movements of the south Armorican shear zone are not better established.

\section{Acknowledgements}

I thank Dr. V. Renard, Dr. X. Le Pichon and Dr. J. Francheteau for critically reading the manuscript and offering helpful suggestions. Bedford Institute, Cambridge University and the French Service Hydrographique et Océanographique de la Marine gave me gravimetric data in the Bay of Biscay.

\section{References}

[1] J. Cogne, Les grands cisaillements hercyniens dans le massif Armoricain et les phénomenes de granitisation. Etages tectoniques, La Baconnière, Neuchâtel, Suisse, Colloque de Neuchâtel, 18-21 avril 1966, (1966) pp. 179-192.

[2] J. Cogne, Le massif Armoricain et sa place dans la structure des socles ouest-européens: l'arc hercynien ibéroarmoricain, dans: Histoire structurale du golfe de Gascogne. Ed. Technip. Publ. Inst. Franç. Pétrole, Coll. Colloques et Séminaires, 22, t. 1, I. 1-1 - I. 1-24 (1971).

[3] J.P. Bard, R. Capdevila et P. Matte, La structure de la chaine hercynienne de la meseta iberique: comparaison avec les segments voisins, dans: Histoire structurale de golfe de Gascogne, Ed. Technip. Publ. Inst. Franç. Petrole, Coll. Colloques et Séminaires, 22, t. 1, I. 4-1 I. 4-68 (1971).

[4] Ch. Barrois, Les grandes lignes de la Bretagne, dans: Livre jubilaire de la Soc. Géol. Fr. I, (1930) pp. 83-100.

[5] J. Cogne, Zones stables et zones mobiles au cours de l'orogénèse hercynienne dans le massif Armoricain, relations avec le champ de la pesanteur, Mém. Bur. Recherches Géol. Minières 52 (1967) 15 .

[6] M.J. Graindor, Les dislocations majeures du socle armoricain, Mém. Bur. Recherches Géol. Minières 52 (1967) 25.
[7] J.R. Vanney, G. Scolari, F. Lapierre, G. Martin et A. Dieucho, Carte geologique provisoire de la plate-forme armoricaine (décembre 1970), dans: Histoire structurale du golfe de Gascogne. Ed. Technip. Publ. Inst. Franç. Pétrole, Coll. Colloques et Séminaires, 22, t. 1, III. 1-1 III. 1-20 (1971).

[8] G. Boillot, P. Bouysse and M. Lamboy, Morphology, sediments and quaternary history of the continental shelf between the straits of Dover and Cap Finisterre, in: The Geology of East Atlantic Continental Margin, ICSU/SCOR working party 31, Symp. Cambridge 1970, Report 70/15, I.G.S. (1970) pp. 75-90.

[9] G. Boillot, R. Horn et J.P. Lefort, Evolution structurale de la Manche occidentale au Secondaire et au Tertiaire, Coll. Gél. de la Manche, Paris, 14-15 janv. 1971, in press (1972).

[10] P. Andreieff, P. Bouysse, R. Horn et G. Mongiardini, Geologie des approches occidentales de la Manche, C.R. Acad. Sci. Paris 270 (1970) 2756.

[11] L. Chauris, J. Deunff, F. Lapierre, J.P. Lefort et Y. Plusquellec, Les formations pré-cambriennes et paléozoìques du large des côtes occidentales du Finistère, C.R. Acad. Sci. Paris 274 (1972) 2624.

[12] M. Bacon, F. Gray and D.H. Matthews, Crustal Structure Studies in the Bay of Biscay. Earth Planet. Sci. Letters 6 (1969) 377.

[13] M. Bacon and F. Gray, A gravity survey in the Eastern part of the Bay of Biscay, Earth Planet. Sci. Letters 10 (1970) 101.

[14] H. Neth and M.S. Snellius, Bathymetric, magnetic and gravity investigations, Navado III (1967) 1964.

[15] Carte gravimétrique de la France, Bureau de Recherches Géologiques et Minières (1964).

[16] F.J. Davey, Bouguer Anomaly maps of the North Celtic sea and entrance to the Bristol Channel, Geophys. J. Roy. Astron. Soc. 22 (1970) 277.

[17] M.H.P. Bott and S.B. Smithson, Gravity investigations of subsurface shape and mass distributions of granite batholiths, Geol. Soc. Amer. Bull. 78 (1967) 859.

[18] C. Weber, Le prolongement oriental des granites de Lanvaux d'après la gravimétrie et l'aéromagnetisme, Mém. Bur. Recherches Geol. Minières 52 (1967) 83.

[19] X. Le Pichon, J. Bonnin, J. Francheteau et J.C. Sibuet, Une hypothèse d'évolution tectonique du golfe de Gascogne, dans: Histoire Structurale du golfe de Gascogne. Ed. Technip. Publ. Inst. Franç. Pétrole, Coll. Colloques et Séminaires, 22, t. 2, VI. 11-1 - VI. 11-44.

[20] X. Le Pichon and J.C. Sibuet, Comments on the evolution of the North-East A tlantic, Nature 233 (1971) 257.

[21] J.C. Sibuet, Contribution de la gravimétrie à l'étude de la Brétagne et du plateau continental adjacent, C.R. Somm. S.G.F. (in press) (1972). 